\title{
The Cause of 100-year Low Carbonated Concrete of the Bridge
}

\author{
Ivan Janotka ${ }^{1, *}$, Michal Bačuvčík', Lukáš Húlek', Peter Paulík \\ ${ }^{1}$ Department of Material Research, Building Testing and Research Institute, Studená 3, Bratislava, 821 04, Slovakia \\ ${ }^{2}$ Department of Concrete Structures and Bridges, Faculty of Civil Engineering of Slovak University of Technology, \\ Radlinského 11, Bratislava,810 05, Slovakia
}

*Corresponding author: E-mail: janotka@tsus.sk; Tel.: (+421) 918943972

DOI: $10.5185 /$ amlett.2020.021470

During the research study focused on 100 years, old concrete bridges in Slovakia an unexpected observation was made. Two bridges were found with a very low carbonation depth under an ordinary cement-based render coat used at the time of its construction for aesthetic reasons. The average measured value by phenolphthalein test was less than $2 \mathrm{~mm}$ after more than 100 years of service life in exposure class XC3 of EN 206. The remaining investigated bridges, from this period of construction, exposed to the same environment and made of concrete of comparable quality, showed significantly higher carbonation depths. Low carbonation depth, can be explained by the presence of a thin (2-4 $\mathrm{mm}$ ) layer of the protective render coat (PRC) applied to concrete surface around 100 years ago. The place, where the PRC was of good quality was almost impermeable and the carbonation of the concrete underneath was even $0 \mathrm{~mm}$. A narrow free space filled with the carbonates can cause increased nonpermeability of the thin PRC creating thus the best condition for the built limestone-based (anticarbonation) barrier with the ability to dramatically reduce $\mathrm{CO} 2$ penetration into the beneath concrete over time. This article is focused on the probable explanation of this phenomenon.

\section{Introduction}

The carbonation reactions of cement-based materials a) occur in natural environment at a very slow rate due to the low $\mathrm{CO}_{2}$ concentration (400 ppm or $0.04 \%$ ) in the atmosphere [1]; b) are the highest within the R. H. range $50-70 \%[2,3]$ and c) are largely controlled by the diffusion rate of $\mathrm{CO}_{2}$ through the microstructure groundmass [4-6]. The differences in $\mathrm{CO}_{2}$ concentration and $\mathrm{R}$. $\mathrm{H}$. produce different amounts of carbonates [7] and thus alter the carbonation rate of $\mathrm{Ca}(\mathrm{OH})_{2}$ and gel-like calcium silicate and aluminum hydrates (C-S-H and C-A-H) [8]. The $\mathrm{pH}$ of the pore solution, mineralogy, and pore structure of the carbonated concrete depend on the $\mathrm{CO}_{2}$ concentration as well [9]. The state of concrete and embedded reinforcement depends, to a large extent on its long-term exposure and other surrounding factors $[\mathbf{1 0 , 1 1}]$. When the matured concrete is attacked, the $\mathrm{CO}_{2}$ penetration depth is mostly limited to the outer layer because of the slow diffusion rate through the dense microstructure. In such a condition, the increase in strength of OPC-based systems due to the carbonation is not prominent $[\mathbf{1 2 , 1 3}$. During the carbonation reaction, $\mathrm{Ca}(\mathrm{OH})_{2}$ is gradually converted into $\mathrm{CaCO}_{3}$, which reduces the alkalinity of the concrete. Hence, the carbonation of OPC-based concrete makes the reinforcement more vulnerable to corrosion [14]. Carbonation reaction leads to a reduction in total porosity as the molar volume of the reaction product $\mathrm{CaCO}_{3}$ is higher $\left(36.93 \mathrm{~cm}^{3} / \mathrm{mol}\right)$ than the primary reactant $\mathrm{Ca}(\mathrm{OH})_{2}$ $\left(32.29 \mathrm{~cm}^{3} / \mathrm{mol}\right)[7,15]$. Because of the reduction of total porosity, the carbonation reaction firstly reduces the permeability $[\mathbf{7 , 1 6}]$ and increases the microhardness of the cementitious matrix [17]. Although the carbonation reaction reduces the total porosity, it changes the pore size distribution at the same time by increasing the proportion of capillary pore sizes greater than $30 \mathrm{~nm}$ [18]. Due to the increase in capillary porosity, further progressing carbonation increases the diffusivity of ions through the cementitious matrix and finally the permeability [19]. This phenomenon results in more extensive carbonation shrinkage connected with crack propagation. The relation between mixture composition and carbonation resistance is in a detail assessed in the papers [20-23] and the major conclusions from the study are listed below.

1. Depending on the type of mineral additive and extent of clinker substitution the carbonation coefficient value of concrete was found to vary. Mixtures with similar clinker replacement levels but with different types of mineral additives showed a noticeable difference in carbonation resistance. The carbonation coefficient was found to increase with the increase in the clinker replacement level with SCMs.

2. Ranking of different mixtures in order of the carbonation resistance stays the same at all the carbon dioxide concentrations used.

3. A linear relationship was observed between the natural and accelerated carbonation coefficient values implying the use of adopted concentration of carbon dioxide to study the performance of concrete under carbonation in a shorter duration. 


\section{Advanced Materials Letters www. vbripress.com/aml}

4. No correlation between the rate of carbonation and compressive strength/porosity of concrete was evident among all the types of cement. However, a slightly better correlation was observed between them if types of cement having similar clinker replacement levels were considered together.

5. As opposed to physical parameters of concrete, a reasonable correlation was observed between chemical parameters describing carbon dioxide buffer capacity of cement and rate of carbonation in concrete.

6. An empirical equation is developed to predict carbonation depth in Portland cement and blended types of cement. The empirical equation developed takes into consideration the effect of chemical and mechanical properties of cement along with environmental parameters like carbon dioxide concentration, relative humidity, and temperature. The estimated values of the natural carbonation coefficient show a reasonable correlation with experimentally calculated carbonation coefficient values for all the types of cement used in this study.

During the research of 100 years, old concrete bridges in Slovakia two bridges were found with a very low carbonation depth. The average measured value by the phenolphthalein test was less than $2 \mathrm{~mm}$ (even $0 \mathrm{~mm}$ ) after more than 100 years of service life. The repeated tests carried out by 3 independent teams (the Technical University of Bratislava and Žilina, and TSÚS) either onsite or in the laboratory confirmed low carbonation rate and therefore detailed investigation has begun. Our article is focused on the explanation of this phenomenon, which lays in an old surface treatment of concrete used at that time on the construction site, as we think, for an aesthetic reason.

\section{Methods used}

The work includes the execution of in-situ and/or laboratory mechanical tests, the estimations of mineralogical, phase and chemical composition, and the pore structure parameters of the structural concrete at the old bridges. In 2014-2015 in-situ and laboratory tests of 7 old bridges: Bratislava - the year of construction 1891, Hlohovec-1910, Krásno nad Kysucou-1891, Nyiregháza 1885 (presently in Hungary, tests performed in the cooperation of Hungary and Slovakia), Sládkovičovo- before 1920, Ružomberok-1912 and Nižná Myšl'a- before 1920, were carried out. The bridge in Sládkovičovo with the found protective render coat (PRC) was firstly tested in 2015 and repeatedly in 2018 [24-27].

The overall diagnostics of the old bridges, including Sládkovičovo, was divided into four main phases. The first phase was concerned by visual observation of the bridge and site-determinations for consequent testing, the second included the whole non-destructive testing and taking the concrete cores for laboratory mechanical, microstructure and pore structure tests. The third phase consisted of extensive laboratory tests described below. The fourth, now experimentally ongoing phase, deals with

the development of modern surface treatment from today's materials.

In-situ tests applied in the current project concerned the following procedures: 1) testing concrete by hardness method using Schmidt hammer, model $\mathrm{N}$ according to STN 731373 [28], 2) ultrasonic examination of concrete by STN 731371 [29] using PUNDIT apparatus searching for the homogeneity of concrete material and hence the mechanical properties (Fig. 1a), 3) measurements of surface tensile strength of concrete using square breakaway targets according to STN EN 12636 [30] (Fig. 1b and Fig. 2), 4) measurements of surface permeability of concrete and protective render coat (PRC) by Torrent air permeability test [31] for checking the surface permeability of uncovered and covered concrete by the PRC (Fig. 3a and Fig. 3b) and 5) carbonation depth by phenolphthalein test. The taken cylindrical cores with diameter $100 \mathrm{~mm}$ and length at least $300 \mathrm{~mm}$ were tested in the TSÚS laboratory (Fig. 4) for volume density (VD), dynamic modulus of elasticity (DME), Young's (static) modulus of elasticity (YME) [32] (Fig. 5) and compressive strength (CP) [33].

(a)

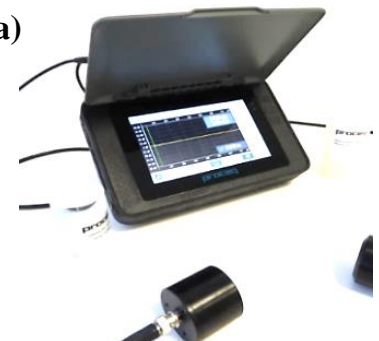

Fig. 1. Device for the on-site measurement of dynamic modulus of elasticity.

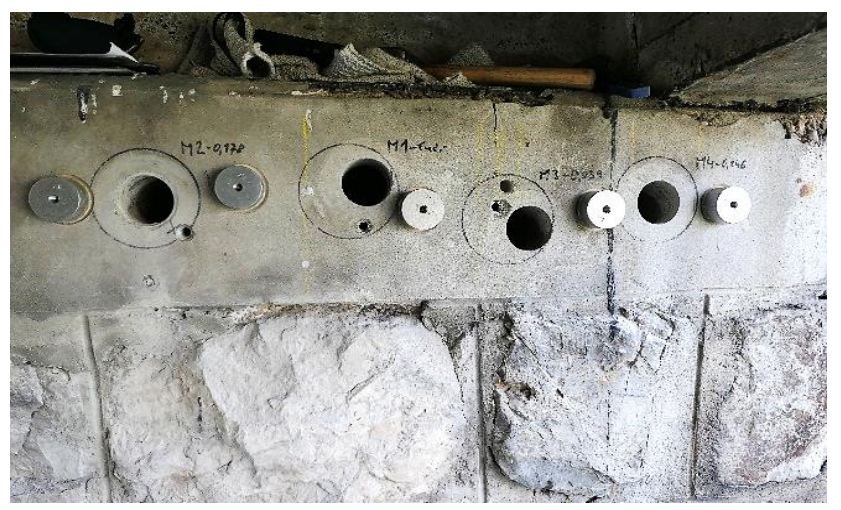

Fig. 2. Device for the on-site measurement of surface tensile strength.
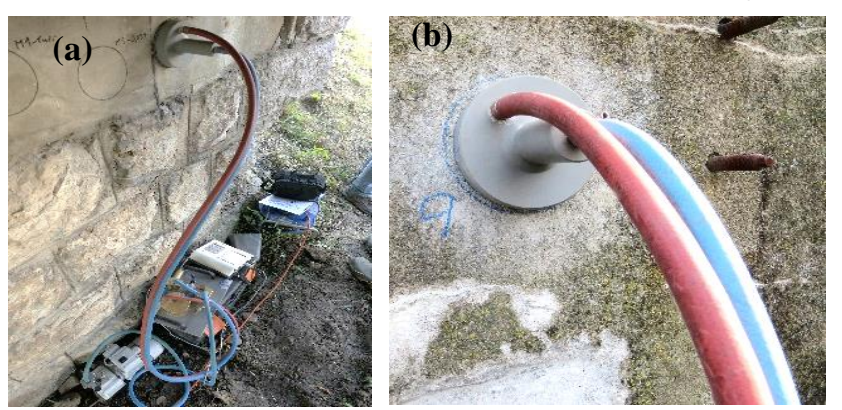

Fig. 3. Device for the on-site surface permeability measurement. 


\section{Advanced Materials Letters www. vbripress.com/aml}

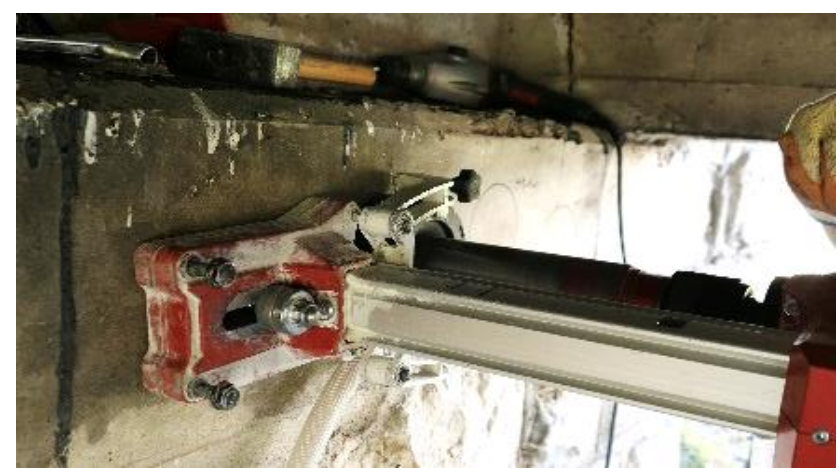

Fig. 4. Taking the cylindrical cores from a bridge.

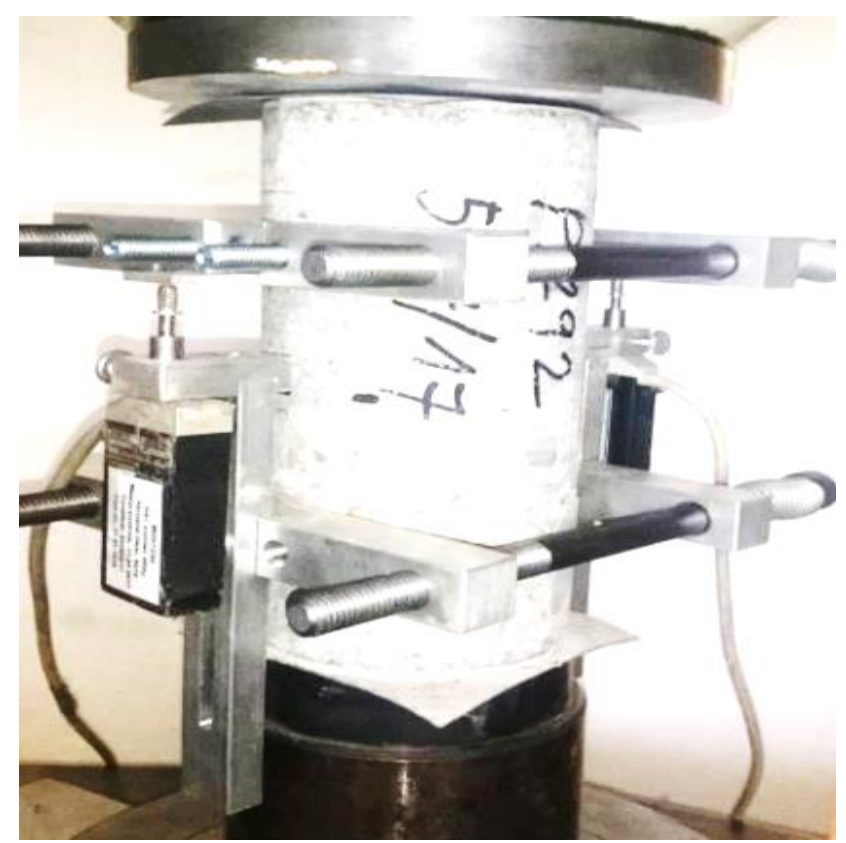

Fig. 5. Measurement of Young's modulus of elasticity.

Descriptions of the test methods, mainly the procedures applied in Slovak Technical Standards (STN, STN ISO) are reported in a detail in the papers [2427]. The cylindrical concrete specimens were half broken in the laboratory by longitudinal splitting. Phenolphthalein test was repeated on the first part and the second part was used to study the microstructure and pore structure. Consequently, two sub-samples were chosen for in-deep detail verifications - surface: directly exposed to prolonged exposure to $\mathrm{CO}_{2}$ and - internal: covered with an overlay of concrete kept out of direct contact with open air. Subsequently, the sub-samples were crushed, heated at $60{ }^{\circ} \mathrm{C}$ to constant weight and ground for fineness passing $0.063 \mathrm{~mm}$ for next analytical procedures. Chemical analysis of the ground concrete matrix (without large aggregate grains) was performed in concordance with STN 72010 [34]. The X-ray diffraction tests were made on the automatic theta/theta X-ray diffractometer STOE \& Cie $\mathrm{GmbH}$ (Germany) using the program Bede ZDS W95/98/NT for assessing the records and run in a $2 \Theta$ range of $5-65^{\circ} . \mathrm{CuK}_{\alpha}$ radiation and $\mathrm{Ni}$-filter were used. Thermal studies were conducted simultaneously from 20 to $1100{ }^{\circ} \mathrm{C}$ at the NETZSCH apparatus STA $449 \mathrm{~F} 3$
Jupiter (Germany). Samples weighing $200 \mathrm{mg}$ were heated in flowing air within the heating range $20-1100{ }^{\circ} \mathrm{C}$ and at heating rate $10{ }^{\circ} \mathrm{C} /$ minute. The pore structure was studied by mercury intrusion porosimetry (MIP) on the porosimeter Poremaster GT-60, Quantachrome (USA) using approximately 5-10 g bulk samples of the concrete matrix without large aggregate grains. The microstructure of bulk concrete samples (without large aggregate grains) was studied by scanning electron microscopy on the JEOL $7500 \mathrm{~F}$ apparatus (Japan). The samples were fixed using a two-component epoxy paste in aluminum discs with a diameter of $25 \mathrm{~mm}$, which are used to transfer the sample to the interior of the microscope. These prepared samples were plated with a mixture of gold-palladium under argon. For plating the spreader device Balzers was used. The image was captured electronically using the program "PC SEM" (version 3.0.1.8). Optical microscopy was carried out on a digital device VHX-5000 with CMOS image sensor $1 / 18$ virtual pixels $1600(\mathrm{H}) \times 1200(\mathrm{~V})$ from Keyence International (Belgium). The present state of concrete is assessed on the base of the above set of the obtained results.

To narrow the scope of information, this article is mainly focused on the bridge Sládkovičovo with the observed negligible depth of carbonation. Carbonation was assessed by the own methodology based mainly on TG-DTA analysis supplemented by the XRD technique. These techniques in concrete containing limestone and dolomite stone failed to distinguish the origin of carbonates: the one when calcite is formed by the carbonation from the one when it is derived from the used aggregate. The reliable use of TG-DTA and XRD techniques is guaranteed in concrete made with siliceous aggregate. The results of chemical analysis are unavoidably necessary for the calculation of the degree of carbonation of concrete. The detailed experimental program and procedure of the carbonation attack, as described at the bottom text, is specified in the article [35]. The mineralogical composition of the aggregates confirmed $\mathrm{SiO}_{2}$-based character.

The degree of carbonation (CD) as the $\mathrm{CaO}_{\text {Carb }} / \mathrm{CaO}_{\text {Total }}$ ratio $\times 100$ (\% wt.), was calculated from TG-DTA results and chemical analysis. $\mathrm{CaO}_{\text {Carb }}$ means the $\mathrm{CaO}$ content bound in $\mathrm{CaCO}_{3}$ originated from carbonation reaction and $\mathrm{CaO}_{\text {Total }}$ concerns $\mathrm{CaO}$ bound in $\mathrm{CaCO}_{3}$, $\mathrm{Ca}(\mathrm{OH})_{2}$, gel-like hydration products (C-S-H and C-A-H) and $\mathrm{CaSO}_{4} \times 2 \mathrm{H}_{2} \mathrm{O}$. The extent of the carbonation attack is also specified by the degree of modification changes (DMC) given by the $\mathrm{CaCO}_{3}$, coarse-grained $/ \mathrm{CaCO}_{3}$, fine-grained ratio. The fine-grained $\mathrm{CaCO}_{3}$ is detected by TG-DTA between $600-750{ }^{\circ} \mathrm{C}$ and coarse-grained $\mathrm{CaCO}_{3}$ between $750-1100{ }^{\circ} \mathrm{C}$. The higher DMC value, the more intense carbonation extent is observed because of the increased portion of coarse-grained opposite to fine-grained carbonates $\mathrm{CaCO}_{3}$ in the concrete. Based on plenty of previous results [e. g. 36, 37, 38 and 39] the extent of $\mathrm{CO}_{2}$ attack is characterized by four stages of carbonation (I < $55 \%$; II: 55 - $65 \%$; III. 66 - $80 \%$; IV. > $80 \%$ ). 


\section{Advanced}

\section{Experimental}

\section{Materials / chemicals details}

Four drilled cores were taken from the bridge Sládkovičovo (SL) in 2015. The attention was paid to the effect of the PRC with a focus on the relationship between the permeability and the efficiency of the PRC cover to prevent $\mathrm{CO}_{2}$ ingress into the concrete beneath. The volume density, dynamic modulus of elasticity, Young's (static) modulus of elasticity and compressive strength of concrete uncovered by the PRC (SL-NON), given as a representative specimen with 100 years aggressive action of $\mathrm{CO}_{2}$ are $2110 \mathrm{~kg} / 3,30.8 \mathrm{GPa}, 16.1 \mathrm{GPa}$, and 20.3 MPa. For comparison, the same data for surface-protected concrete by the PRC (SL-COV) with up to zero carbonation depth over 100 years are $2160 \mathrm{~kg} / \mathrm{m}^{3}, 35.9$ $\mathrm{GPa}, 20.3 \mathrm{GPa}$, and 25.3 MPa. The depth of carbonation measured by phenolphthalein test was for the PRC SLNON - around $60 \mathrm{~mm}$, while that of SL-COV was even zero millimeters. The next range of experiments was conducted in 2018 with the far wider scope of on-site tests performed on the bridge, which were followed by laboratory tests using cylindrical cores $(\mathrm{d}=100 \mathrm{~mm}$, $\mathrm{h}=\min .300 \mathrm{~mm}$ ). The composition of the old concrete, as well as the PRC, was not known; therefore, these data are not presented. Fig. 6 shows two concrete specimens taken from the bridge: that on the left is the PRC-covered and on the right shows uncovered surface. The fragments of the PRC placed on the concrete surface are illustrated in Fig. 7.

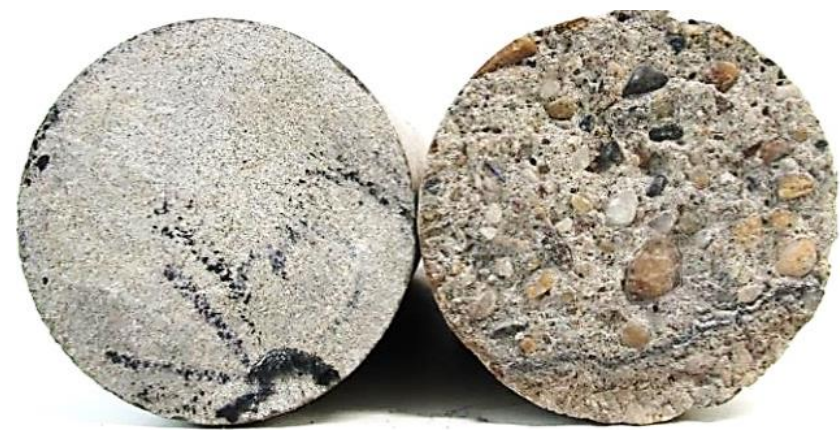

Fig. 6. Concrete from the bridge Sládkovičovo covered (left) and uncovered (right) by the PRC.
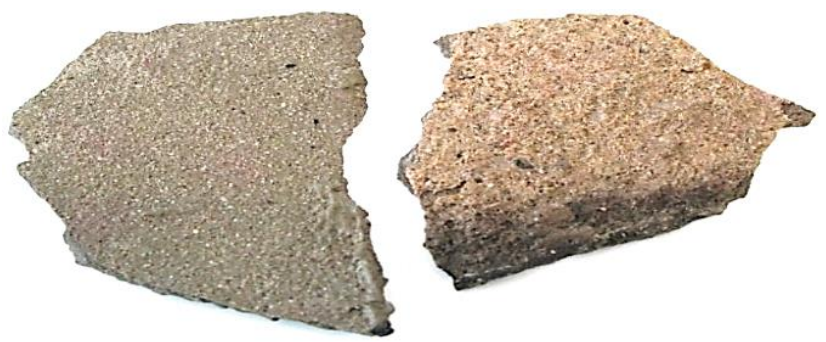

Fig. 7. Fragments of the PRC from outside (left) and inside view (right)) of the concrete base.

\section{Results and discussion}

The content of $\mathrm{CaCO}_{3}$ as the carbonation product in the surface $0-20 \mathrm{~mm}$ layer of uncovered and surfaceprotected concrete (SL-NON-1, SL-COV-1) as well as in the internal 150-180 mm layers (SL-NON-2 and SL-COV2) and the PRC are listed in Table 1.

Table 1. The evaluation of thermal analysis results by TG calculations.

\begin{tabular}{c|c|c}
\hline Sample & $\begin{array}{c}\mathbf{C a C O}_{3} \\
\text { content } \\
(\% \text { wt.) }\end{array}$ & $\begin{array}{c}\text { Increase in } \mathrm{CaCO}_{3} \text { content } \\
\text { between surface and internal } \\
\text { layer (\% wt.) }\end{array}$ \\
\hline SL-NON-1 & 18.33 & 10.32 \\
\hline SL-NON-2 & 8.01 & 0.72 \\
\hline SL-COV-1 & 10.07 & - \\
\hline SL-COV-2 & 9.35 & \multirow{2}{*}{0.26} \\
\hline SL-PRC & 26.22 & \\
\hline
\end{tabular}

The unprotected concrete SL-NON - demonstrates an evident increase in $\mathrm{CaCO}_{3}$ content $(10.32 \%$ wt.) in the surface $0-20 \mathrm{~mm}$ layer (NON-1) compared to the internal $150-180 \mathrm{~mm}$ (NON-2), whereas this difference is negligible in the surface-protected concrete COV-1 vs. COV-2 that takes only $0.72 \%$ wt. Based on the obtained results the main characteristics of the extent of carbonation attack are summarized in Table 2. From the data of thermal analysis, the amount of $\mathrm{CaO}_{\text {Carb }}$ bound in fine-grained and coarse-grained $\mathrm{CaCO}_{3}$ was calculated. The total content of the present $\mathrm{CaO}\left(\mathrm{CaO}_{\text {Total }}\right)$ was obtained from chemical analysis. The degree of carbonation (CD), the degree of modification changes (DMC) and the stage of carbonation (SC) were calculated from these data as the main indicators of the carbonation attack.

Table 2. Assessment of the carbonation attack by main characteristics showing the extent of carbonation.

\begin{tabular}{c|c|c|c|c|c|c|c}
\hline Sample & $\begin{array}{c}\text { CaO } \\
\text { total } \\
(\%\end{array}$ & \multicolumn{3}{|c|}{\begin{tabular}{c}
\multicolumn{2}{|c|}{$\mathbf{C a O}_{\text {Carb }}$} \\
(\% wt.) occurring in
\end{tabular}} & \multicolumn{3}{|c}{$\begin{array}{c}\text { Assessment of } \\
\text { carbonation }\end{array}$} \\
\cline { 3 - 5 } & wt.) & $\begin{array}{c}\text { fine - } \\
\text { grained } \\
\text { CaCO }\end{array}$ & $\begin{array}{c}\text { coarse- } \\
\text { grained } \\
\text { CaCO }\end{array}$ & Total & $\begin{array}{c}\text { CD } \\
(\%)\end{array}$ & $\begin{array}{c}\text { DMC } \\
(-)\end{array}$ & $\begin{array}{c}\text { SC } \\
(-)\end{array}$ \\
\hline $\begin{array}{c}\text { SL- } \\
\text { NON-1 }\end{array}$ & 9.09 & 2.40 & 7.87 & 10.27 & 113.0 & 3.3 & IV \\
\hline $\begin{array}{c}\text { SL- } \\
\text { NON-2 }\end{array}$ & 8.51 & 1.40 & 3.08 & 4.49 & 52.7 & 2.2 & I \\
\hline $\begin{array}{c}\text { SL- } \\
\text { COV-1 }\end{array}$ & 9.86 & 1.77 & 3.87 & 5.64 & 57.3 & 2.2 & II \\
\hline $\begin{array}{c}\text { SL- } \\
\text { COV-2 }\end{array}$ & 7.06 & 1.41 & 2.83 & 4.24 & 60,0 & 2,0 & II \\
\hline SL-PRC & 29.11 & 5.05 & 10.19 & 15.24 & 52.4 & 2.0 & I \\
\hline
\end{tabular}

The similarity in the carbonation extent between SLCOV-1 and SL-COV-2 samples is caused by the PRC's property to reduce the $\mathrm{CO}_{2}$ penetration into the concrete beneath. For this reason, the carbonation of the surface 0 $20 \mathrm{~mm}$ (SL-COV-1) and internal 150-180 mm (SL-COV2) concrete layer covered by the PRC (coefficient of permeability $\mathrm{K}=0.073 \times 10^{-16} \mathrm{~m}^{2}$ ) is almost the same. By contrast, the surface $0-20 \mathrm{~mm}$ layer of uncovered SLNON-1 sample is carbonated and shows the IV stage of carbonation. The protective render coat records the degree of carbonation proportional to the stage of carbonation I despite the confirmed largest content of $\mathrm{CaCO}_{3}$. This finding implies two facts: 1) the PRC is after 100 years of service-life attacked by carbonation only to the harmless level and 2) the largest content of $\mathrm{CaCO}_{3}$ is not regarded 


\section{Advanced Materials Letters www. vbripress.com/aml}

as the only one important critical factor determining the extent of carbonation.

The low-permeable PRC $\left(\mathrm{K}=0.073 \times 10^{-16} \mathrm{~m}^{2}\right)$ placed at the concrete surface acts as a protective barrier preventing $\mathrm{CO}_{2}$ diffusion over time. The results show that there are many carbonates collected in the tight space of the thin PRC layer. The high $\mathrm{CaCO}_{3}$ content implies that actual non-permeability is mainly due to the sequential deposition of carbonates in a PRC over time. This hypothesis is examined by the present research. However, one would assume high-material quality and technological discipline at placing the PRC as surface protection on the bridge concrete as well as no crack propagation and occurrence or any type of other mechanical damage of the PRC during the service life of concrete (bridge) structure. Today, the origin reason for PRC applying approximately 100 years ago is not clear but it has been just approved that this layer can act as an anti-carbonation barrier. It might be kept in mind that no chemical admixtures or additions, if any - only natural, were used at the manufacture of a concrete or PRC in such past time. It is stated that the observed low carbonation depth of underlying concrete can be explained by the protective effect of a thin PRC layer non-permeable for $\mathrm{CO}_{2}$. The places, where the render coat was of good quality were found almost impermeable and the carbonation of concrete underneath was negligible (less than $2 \mathrm{~mm}$, even $0 \mathrm{~mm}$ ). Repeated measurements in 2018 confirmed the protecting function of the PRC. Even if the concrete was covered by a low-quality PRC it had much lower carbonation depth than concrete at places where the protective render coat spalled over time. Fig. 8 shows the graphical evaluation of the results gained in 2015 (samples A1 to A4) and by the repeated tests in 2018 (M1 to M10) and B1 sample as the uncovered reference concrete. In aby case the PRC, also if cracked or interface zone between concrete and PRC was disturbed, reduced the $\mathrm{CO}_{2}$ penetration into the underlying concrete. High-quality, impermeable PRCs showing no defects at the interface zone with the concrete (samples M3, M4, M9 and M10 of 2018 and A2, A3 of 2015) are characterized by very low, even zero carbonation depth, while the uncovered concrete without surface protection by a PRC even $80 \mathrm{~mm}$ carbonation depth.

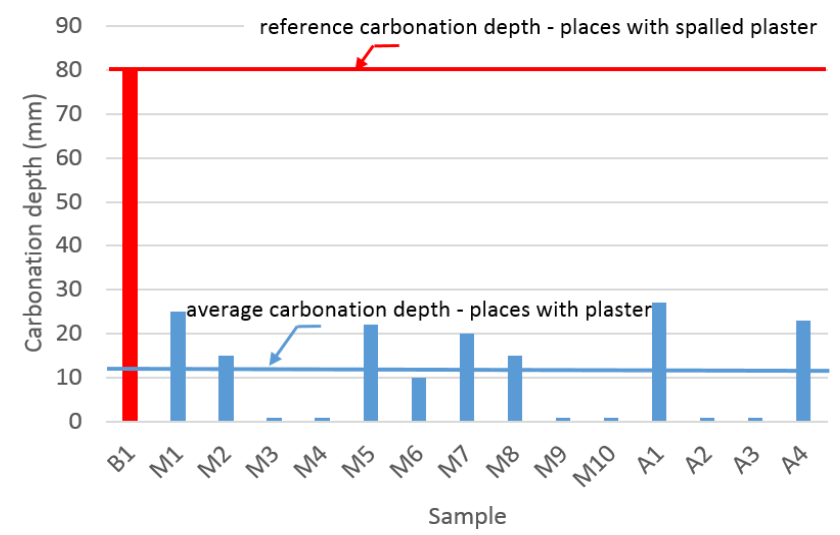

Fig. 8. Carbonation depth of concrete below the protective render coat and on places where the PRC spalled.
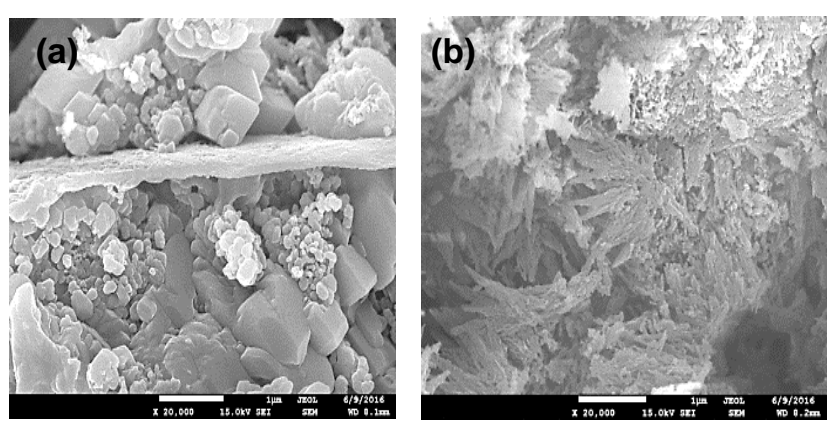

Fig. 9. Microstructure of uncovered 0-20 mm surface concrete SL-NON1(a) and surface-protected concrete by the PRC (b).

The coefficients of permeability $\mathrm{K}$ related to $\mathrm{M}$ $(3,4,9$ and 10) samples are $(0.039,0.246,0.189$ and $0.062 \times 10^{-16} \mathrm{~m}^{2)}$, while the B1 sample has extremely high, already immeasurable permeability. Fig. 9a and Fig. 9b illustrate differences between the microstructure of the unprotected concrete surface, and surface-protected by the PRC. Concrete with direct contact to air demonstrates the evident amount of the coarse crystallized carbonation products, while that protected by the PRC is densified by fine-grained carbonate alternates. The reduced content of coarse-grained $\mathrm{CaCO}_{3}$ in the original, 100 - year - old PRC can be attributed to a narrow space capable of its formation. When yet formed, the spatial deficiency of the PRC does not allow further $\mathrm{CO}_{2}$ penetration into the concrete beneath. The carbonation depth of the concrete specimen with the uncovered and covered surface is illustrated in Fig. 10 to Fig. 12.

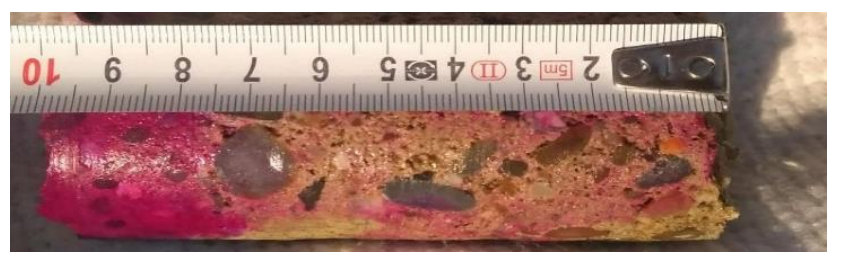

Fig. 10. Carbonation depth of concrete with the uncovered surface by the PRC.

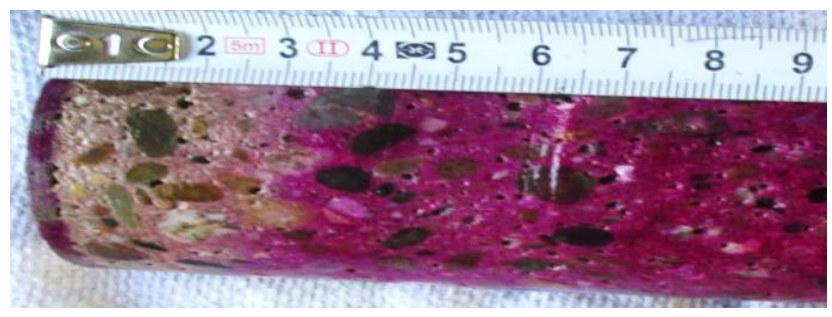

Fig. 11. Carbonation depth of concrete below the render coat characterized by the measured permeability of $80.17 \times 10^{-16} \mathrm{~m}^{2}$.

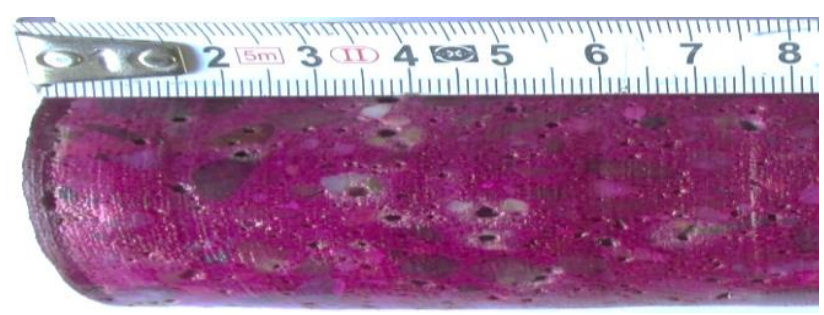

Fig. 12. Carbonation depth of concrete below the render coat characterized by the measured permeability of $0.073 \times 10^{-16} \mathrm{~m}^{2}$. 


\section{Advanced Materials Letters www. vbripress.com/aml}

The prevailingly fine-grained character of the formed dense, as if sintered, carbonates in confined spatial conditions inside the $2-4 \mathrm{~mm}$ thin PRC creates the best condition for the built limestone-based barrier with the ability to dramatically reduce $\mathrm{CO}_{2}$ penetration into the beneath concrete over time.

Considering the above-mentioned facts, it is stated that the low carbonation depth can be explained by the presence of a thin layer of cement-based protective render coat applied to concrete surface 100 years ago. In-situ measurements by the Torrent permeability tests showed a very low permeability of this cement-based layer (PRC)r. Carbonation of the underlying concrete is closely related to the impermeability of the PRC layer as stated in Table 3.

Table 3. Dependence between surface permeability and carbonation depth.

\begin{tabular}{|c|c|c|c|c|}
\hline \multicolumn{2}{|c|}{ Sample } & $\begin{array}{c}\text { Permeability } \\
\text { by Torrent [31] }\end{array}$ & $\begin{array}{c}\text { Carbonation } \\
\text { depth }\end{array}$ & \multirow{2}{*}{ Notes } \\
\hline Denotation & Description & $\begin{array}{c}\mathrm{kT} \\
\left(\mathbf{x 1 0 ^ { - 1 6 }} \mathbf{m}^{2}\right) \\
\end{array}$ & $(\mathbf{m m})$ & \\
\hline M3 & \multirow{10}{*}{ PRC } & 0,039 & 0 & \multirow{4}{*}{$\begin{array}{l}\text { high- } \\
\text { quality } \\
\text { PRC and } \\
\text { concrete }\end{array}$} \\
\hline M4 & & 0,246 & 0 & \\
\hline M9 & & 0,189 & 0 & \\
\hline M10 & & 0,062 & 0 & \\
\hline M6 & & 0,123 & 10 & $\begin{array}{c}\text { non-visible } \\
\text { deterior- } \\
\text { ation }\end{array}$ \\
\hline M2 & & 0,178 & 15 & \multirow{3}{*}{$\begin{array}{c}\text { porous } \\
\text { concrete } \\
\text { under PRC }\end{array}$} \\
\hline M7 & & 4,943 & 20 & \\
\hline M8 & & 8,464 & 20 & \\
\hline M1 & & $>10$ & 25 & $\begin{array}{c}\text { crack at } \\
\text { PRC surface }\end{array}$ \\
\hline M5 & & $>10$ & 30 & $\begin{array}{c}\text { cavern } \\
\text { at the } \\
\text { concrete } \\
\text { surface } \\
\text { below PRC }\end{array}$ \\
\hline B1 & $\begin{array}{c}\text { Uncovered } \\
\text { concrete }\end{array}$ & $>10$ & 80 & $\begin{array}{l}\text { damaged } \\
\text { structure of } \\
\text { concrete } \\
\text { being } \\
\text { crumbled }\end{array}$ \\
\hline
\end{tabular}

$>10$ - immeasurably high permeability.

The places, where the PRC was of good quality were almost impermeable and the carbonation of concrete beneath was negligible - less than $2 \mathrm{~mm}$, even zero (see: Fig. 12). Concrete, at places covered with the PRC of higher permeability, had a greater carbonation depth (see: Fig. 11) but it was still significantly less than the carbonation depth at the places, where the PRC spalled (see: Fig. 10). The extremely low permeability of the PRC was partially explained by chemical analysis and electron microscope analysis. The results of these analyses were published in 2018 by the authors of this article [35] and could be summarized as follows:

- the reduced content of coarse-grained $\mathrm{CaCO}_{3}$ in the original 100 years old PRC is attributed to a narrow space capable of its formation. a tight space of the thin PRC layer filled with the carbonates causes increased impermeability of the protective render coat.

- the fine-grained character of the formed dense, as if sintered; carbonates create the best condition for the built limestone-based barrier with the ability to dramatically reduce $\mathrm{CO}_{2}$ penetration into the underlying concrete over time.

- a highly carbonated PRC containing highly compressed carbonate material in a tight space of PRC thus creates an impermeable anti-carbonation barrier.

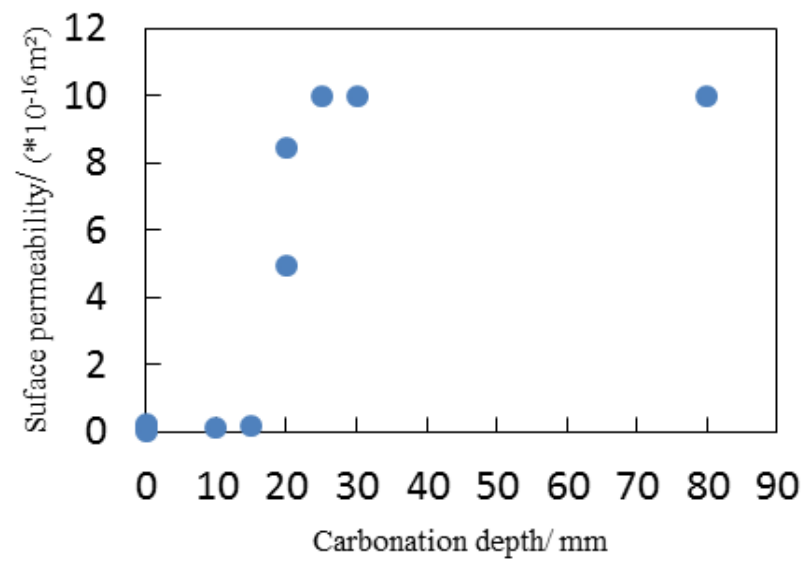

Fig. 13. Dependence between the coefficient of air permeability (surface permeability) and carbonation depth.

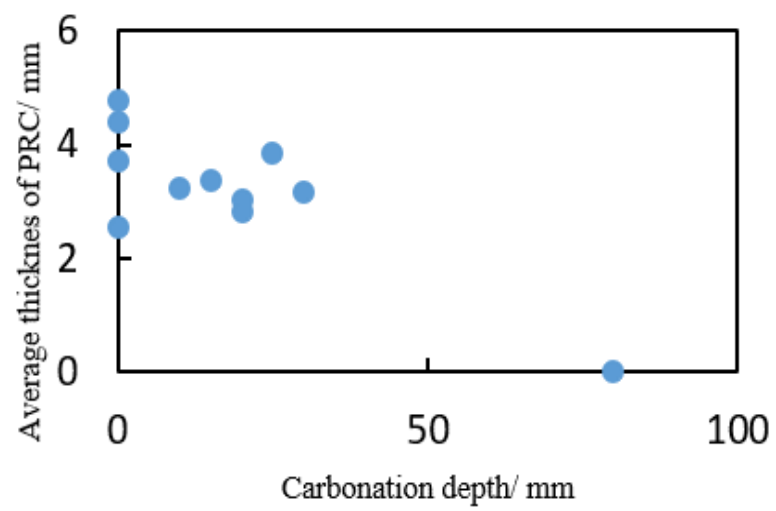

Fig. 14. Dependence between the average thickness of the PRC and depth of carbonation.

The dependence (Table 3) of decisive significance was found between the surface permeability of the PRC and the carbonation depth of the underlying concrete (Fig. 13); the PRC thickness indicates only a minor significance factor (Fig. 14). The PRC impermeability for $\mathrm{CO}_{2}$ penetration is a basic condition for the apparent mitigating and even complete stopping carbonation attack of underlying concrete. The thin PRC layer is characterized by a dense carbonate substance even up to the amorphous state boundary, which is referred to as "carbonate milk" (a designation that has not been used yet). Images from the optical microscope at various magnifications show invisibly but later demonstrably accumulated carbonation milk within the thin PRC layer 


\section{Advanced Materials Letters www. vbripress.com/aml}

(Fig. 15). Shining needles confirm the presence of crystaldeveloped coarser $\mathrm{CaCO}_{3}$ compressed within the PRC thickness. The carbonate milk has such a low permeability with optimally functional PRC (M3, M4, M9, and M10 in Table 3) that the spatially sealed barrier of carbonation products is created in the PRC preventing thus carbonation of 100-year-old concrete effectively.

The same principle of anti-carbonation protection of the bridge concrete was confirmed on the Krásno nad Kysucou bridge $[35,40]$ and also on two other bridges with PRC, the results were not published yet.
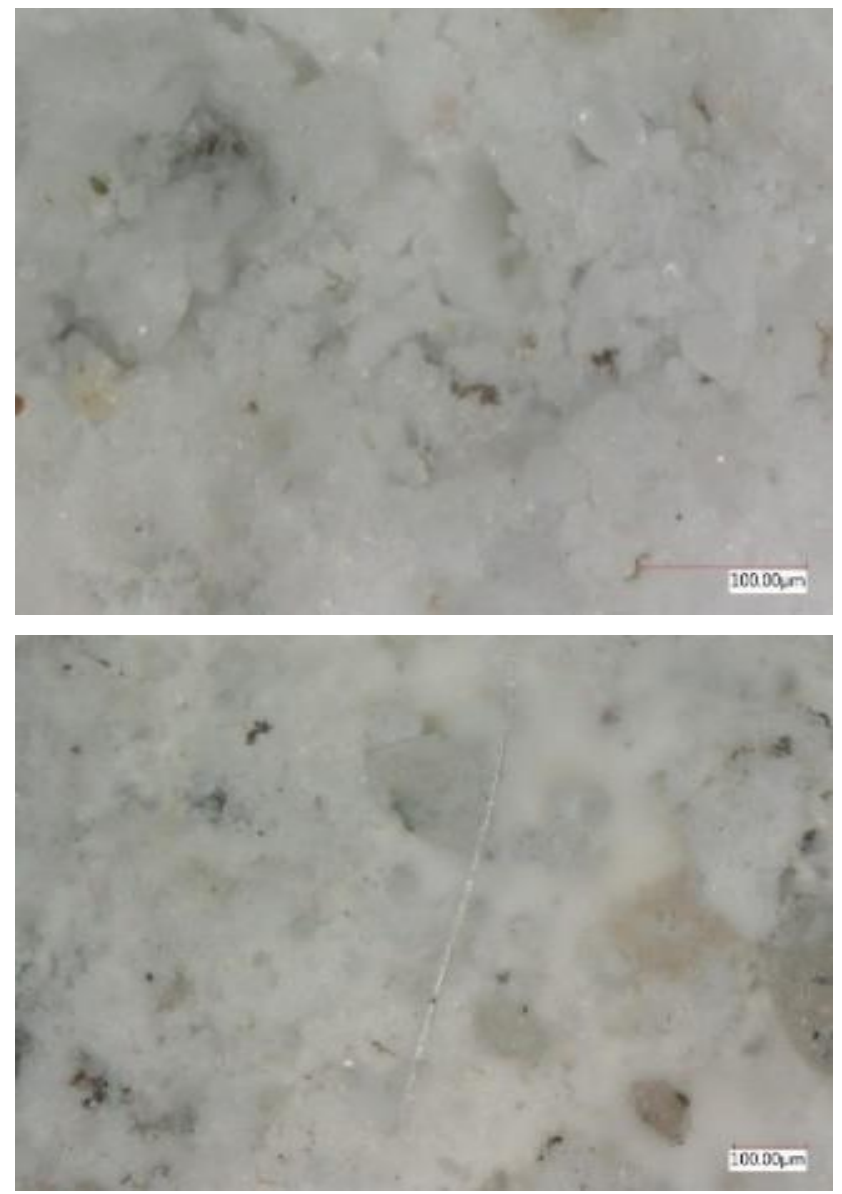

Fig. 15. Dense barrier created from the carbonation products in the space-tight conditions of $3.84 \mathrm{~mm}$ and $2.54 \mathrm{~mm}$ thin PRC M1.

\section{Conclusion}

The following conclusions are based on the results obtained from this study until now:

1) Assessment of aggressive action of $\mathrm{CO}_{2}$ on concrete based on the degree of carbonation, degree of modification changes and four stages of carbonation is an appropriate method for diagnosing the concrete attacked by carbonation for a long time.

2) The 2 - max. $4 \mathrm{~mm}$ layer of thin protective render coat has been proven as an effective anti-carbonation barrier. The formed prevailingly amorphous-like carbonates, regarded as carbonation milk, in a narrow PRC layer densify the tight space in such a way as to create an impermeable barrier to further $\mathrm{CO}_{2}$ ingress preventing further carbonation of the concrete beneath.

3) The results show the close correlation between the surface permeability of PRC and the depth of carbonation of the underlying concrete.

4) The protection of concrete to the carbonation attack is secured by the high-quality PRC placed at the 100year-old bridge concrete surface.

5) The current field experiments are followed by a laboratory phase of PRC development from currently available materials.

\section{Acknowledgments}

The authors wish to express their gratitude to the Slovak Agency for Research and Development (project APVV No. 0442-12) for financing this research work.

\section{Keywords}

Bridge, concrete, carbonation, protective render coat.

Received: 08 August 2019

Revised: 29 November 2019

Accepted: 31 December 2019

\section{References}

1. Berger, R. L.; Young, J. F.; Leung, K.; Nat. Phys. Sci., 1972, 240, 16.

2. Shen, L.; Gao, T.; Zhao, J.; Wang, L.; Liu, L.; Chen, F.; Xue, J.; Renew. Sustain. Energy Rev., 2014, 34, 337.

3. Savija, B.; Lukovic, M.; Constr. Build. Mater., 2016, 117, 285.

4. Bertos, M.F.; Simons, S.J.R.; Hills, C.D.; Carey, P. J.; J. Hazard. Mater., 2004, 112, 193.

5. De Silva, P.; Bucea, L.; Sirivivatnanon, V.; Cem. Concr. R., 2009, 39, 460.

6. Cui, H.; Tang, W.; Liu, W.; Dong, Z.; Xing, F.; Constr. Build. Mater., 2015, 93, 522.

7. Ashraf, W.; Constr. Build. Mater., 2016, 216, 558.

8. Castellote, M.; Fernandez, L.; Andrade, C.; Alonso, C.; Mater. Struct., 2009, 42, 515.

9. Qi Pu; Linhua Jiang; Jinxia Xu; Hongqiang Chu; Yi Xu; Yan Zhang; Construc. Build. Mater., 2012, 28, 519.

10. Anstice, D. J.; Page, C. L.; Page, M. M.; Cem. Concr. Res., 2005, $35,377$.

11. Lagerblad, B.; Carbon dioxide uptake during concrete life cycle State of art, CBI Report 2. Swedish Cement and Concrete Research Institute, 2005, 1-43.

12. Chi, J.M.; Huang, R.; Yang, C. C.; J. Mar. Sci. and Techn., 2002, $10,14$.

13. Chao-Qun Lye; Dhir, R. K.; Ghataora, G. S.; Mag. Conc. Res., 2016, 68, 936.

14. Aguirre-Guerrero, A. M.; Mejla-de Gutiérret, R.; Montees-Correia, M. J. R.; Construc. Build. Mater., 2016, 121, 704.

15. Liu, R.; Jiang, L.; Xu, J., Xiong, C.; Song, Z.; Constr. Build. Mater., 2014, 56, 16 .

16. Claisse, P.A.; Elsayed, H I.; Shaaban, I. G.; ACI Mater. J., 1999, 96, 378.

17. Mo, L.; Panesar, D. K.; Cem. Concr. Compos., 2013, 43, 69.

18. Pihlajavaara, S. E.; Mater. Constr., 1968, 1, 521.

19. Ngala, V. T.; Page, C. L.; Cem. Concr. Res., 1997, 27, 995.

20. Chromá, M.; Rovnaníková, P.; Teplý, B.; Bergmeister, K.; Strauss, A.; Cement -Wapno-Beton, 2014, 2, 81.

21. Shah, V.; Bishnoi, S.; Constr. Build. Mater., 2018, 178, 219.

22. Dutzer, V.; Dridi, W.; Poyet, S., Le Bescop, P., Bourbon, X.; Cem. Concr. R., 2019, 123.

23. Ribeiro A. B.; Santos T.; Gonçalves A.; Constr. and Build. Mater., 2018, 175, 360 .

24. Janotka, I.; Sevcik, P.; Paulik, P.; Bacuvcik, M.; Verification of Concrete Durability of 124 Year Old Bridge in Bratislava. Proc. 


\section{Advanced Materials Letters

Thirteenth Int. Conf. on Recent Advances in Concr. Techn. and Sustain. Issues, Suppl. Papers, Ottawa, 2015, 173.

25. Janotka, I.; Paulik, P.; Sevcik, P.; Bacuvcik, M.; Key Eng. Mat., 2016, 691, 297.

26. Paulik, P., M.; Bacuvcik, M.; Sevcik, P.; Janotka, I.; Material properties study of seven 100-years old concrete bridges in Slovakia, Proc fib Symp. 2016 Performance-Based Approaches for Concr Struct, Cape Town, 2016, Chapter 12: Condition Assessment, Article No. 218

27. Paulík, P.; Janotka, I.; Bačuvčík, M.; Gajdošová, K.; Very low carbonation depth found under ordinary cement render at two old concrete bridges in Slovakia. Proc. fib Symp. Concrete - Innovations in Materials Design and Structures, Cracow, 2019, 2134.

28. STN 73 1373: 1981 Testing of concrete by hardness testing methods. Issued by Slovak Office of Standards, Metrology and Testing, Bratislava, Slovakia.

29. STN 73 1371: 1981 Method of ultrasonic pulse testing of concrete. Issued by Slovak Office of Standards, Metrology and Testing, Bratislava, Slovakia.

30. STN EN 12 636: 2001 Products and systems for the protection and repair of concrete structures. Test methods. Determination of adhesion concrete to concrete. Issued by Slovak Office of Standards, Metrology and Testing, Bratislava, Slovakia.

31. Torrent, R.; Frenzer, G.; Study on methods to determine and judge characteristic values of the cover concrete on site (in German), Bundesamt für Strassenbau, Bern, Germany, 1995, 516, 105.

32. STN ISO 6784: 1993 Concrete. Determination of static modulus of elasticity in compression. Issued by Slovak Office of Standards, Metrology and Testing, Bratislava, Slovakia.

33. STN EN 12390-3: 2010 Testing hardened concrete. Part 3: Compressive strength of test specimens. Issued by Slovak Office of Standards, Metrology and Testing, Bratislava, Slovakia.

34. STN 72 0101: 1973. Basic analysis of silicates. Common regulations and related standards. Issued by Slovak Office of Standards, Metrology and Testing, Bratislava, Slovakia.

35. Janotka, I.; Bačuvčík, M.; Paulík, P.; Case Studies in Constr. Mat., 2018, 8,97 .

36. Matousek, M.; Drochytka, R.; Atmospheric corrosion of concrete (in Czech), Matousek, M. (Edt.); IKAS Prague, Czech republic, 1998, pp.1-186.

37. Jerga, J.; Constr. Build. Mater., 2004, 18, 645.

38. Janotka, I.; Krajci, L.; Concrete deterioration determined by four stages of carbonation, Proc $13^{\text {th }}$ FIP Congr. on Challenges for Concr. in the Next Millennium. Amsterdam, 1998, 1051-1054.

39. Krajci, L.; Janotka, I.; ACI Mat. J., 2000, 97, 168.

40. Janotka, I.; Bačuvčík, M.; Ševčík, P.; Paulík, P.; Physical and chemical state of 124-years old reinforced concrete bridge. Proc. IX. Conf. Concrete Days Wisla, Poland, 2016, Vol 2, 493. 